\title{
KSIĘŻYC A SPRAWA POLSKA
}

Zastosowanie przez Galileusza w badaniach astronomicznych lunety rozszerzyło w pierwszej połowie XVII stulecia zakres obiektów dostępnych dla obserwacji, stwarzając możliwość i potrzebę wprowadzania dla nich nowych nazw. Wzorem stały się nazwy geograficzne, nadawane w epoce wielkich odkryć. Nowa terminologia uwieczniała nieraz imiona odkrywców, ale nie stroniła od akcentów panegirycznych; tak też stało się z nowymi nazwami w astronomii - dedykowano nowoodkryte fragmenty kosmosu możnym tego świata, władcom i mecenasom.

Wraz z pojawiającymi się teraz sporami o pierwszeństwo odkrycia pojawiały się i konkurencyjne nazwy. Pierwszą osobistością tak utrwaloną w astronomii nowożytnej był Kosma (Cosimo) Medyceusz, wielki książę Toskanii, któremu Galileusz zadedykował jako Stellae Mediceae odkryte w 1609 r. cztery satelity Jowisza. Nazwa ta musiała zresztą wkrótce ustapić miejsca tradycyjnym mitologicznym imionom poszczególnych satelitów, zaproponowanym przez konkurenta do priorytetu odkrycia, Simona Maira. Również wokół plam słonecznych, odkrytych niezależnie przez kilku uczonych, narosła lista konkurujących propozycji nazewniczych ${ }^{1}$.

Szczególne znaczenie miało ujawnienie przez Galileusza, dzięki obserwacjom teleskopowym, bogatego ukształtowania powierzchni Księżyca i wyodrębnienie na niej wielkiej liczby górzystych kraterów i pasm górskich wyróżniających się na tle rozległych powierzchni (pojmowanych, w ślad za Plutarchem, jako kontynenty i morza księżycowe). W krótkim czasie zainteresowanie kartografią Księżyca zaowocowało kilkoma projektami nazewnictwa. Najwcześniejsze mapy zawierające systematyczną terminologię obiektów księżycowych opracował w latach 16441645 brukselski uczony, kartograf Michel Florent van Langren (1600-1675), związany z dworem króla Hiszpanii Filipa IV².

Geneza zainteresowań topograficznych Langrena wiąże się z jego próbą opracowania metody wyznaczania długości geograficznej na morzu - zadania niezwykle aktualnego i zaprzątającego od przeszło stu lat uwagę astronomów, geografów i praktyków-nawigatorów. Metoda Langrena polegać miała na określaniu momentów zakrycia przez cień Ziemi jasnych kraterów księżycowych podczas zaćmienia. W 1644 roku Langren wykonał pierwszy szkic mapy przedstawiającej większe, wyróżniające się kratery. Z planowanego szeregu map przedstawiających Księżyc w różnych fazach zrealizowana została - w roku 1645 - tylko jedna, przedstawiająca Księżyc w pełni, grawerowana przez samego Langrena. Mapa ta, zachowana do dzisiaj w czterech egzemplarzach ${ }^{3}$, przedstawia pierwszy konsekwentnie zrealizowany system nazewnictwa księżycowego. Tytuł mapy, „Plenilunii Lumina Austriaca Philippica", sygnalizuje jej przeznaczenie: przedstawia owe 
„lumina”, tj. wyróżniające się kratery wybrane do obserwacji zaćmień, i oddaje ją pod opiekę króla Filipa IV (który też udzielił ochronnego patentu, zabraniającego dokonywania zmian w użytej przez Langrena terminologii).

Na kilka aspektów tej właśnie terminologii warto zwrócić uwagę. Jest to nazewnictwo wyraźnie panegiryczne. Dla „lądów” przyjął Langren nazwy alegoryczne; są to więc Terra Dignitatis, lustitiae, Pacis, Sapientiae, Honoris, Virtutis oraz Laboris. Ciemniejsze powierzchnie „mórz" nazwy swe zawdzięczaja już współczesności (służąc przede wszystkim chwale hiszpańskich Burbonów): wielki Oceanus Philippicus oraz morza: Eugenianym (a więc królowej Eugenii), Austriacum, Belgicum, Borbonicumi, wśród pomniejszych, Astronomicum oraz Langrenianum.

Nazwy ponad 300 kraterów tworzą wielki panegiryczny korowód, od monarchów europejskich, ich małżonek i członków rodzin począwszy. W legendzie mapy Langren wyjaśnił, że wybrał do swej mapy władców - mecenasów nauki: „... hoc plenilunium Philippicum publicamus, propriis Regum ac Principum nominibus collustratum (qui hodie in Europa rerum potiuntur, scientiarumque mathematicarum sunt patroni, fautores, atque Maecenates), aliorum etiam veterum et recentiorum, qui in hoc genere excellunt"

Program ten w realizacji został wyraźnie rozszerzony na większe gremium. Drobniejsze kratery księżycowe noszą więc imiona postaci życia politycznego i osobistości z dworów europejskich. Zgodnie z zapowiedzią znalazło się też miejsce - przede wszystkim w rejonie "Morza astronomicznego" - dla uczonych, od starożytnych aż do czasów współczesnych, ze zmarłym niedawno Galileuszem oraz prowadzącymi właśnie intensywne badania selenograficzne Gassendim i Heweliuszem.

Tak dobitnie realizowana aktualizacja nazw zasługuje na uwagę jako swoisty dokument rangi krajów, wladców i elit europejskich okresu końca wojny trzydziestoletniej w ocenie uczonego - dworzanina z Brukseli.

Szczególne miejsce przypadło oczywiście Filipowi IV: Lángren przyznał mu wielki krater (obecnie: „Kopernik”), wyróżniający się wyraźnie wielkością i jasnymi rozchodzącymi się zeń promieniami na tle równiny Oceanus Philippicus. Innym monarchom (i ich małżonkom) przypadł ciąg wielkich kraterów na Terra Dignitatis między środkiem tarczy księżycowej i jej skrajem południowym. Wyliczając je w tym właśnie porządku, napotyka się na mapie Langrena najpierw kratery papieża Innocentego X i cesarza Ferdynanda III; dalej następują Ludwik XIV i królowa-regentka Anna Austriaczka, Chrystian IV duński, Krystyna królowa szwedzka, Karol I (Stuart) i Wladyslaw IV Waza.

Krater nazwany imieniem polskiego króla zajmuje miejsce na południu tarczy Księżyca. Wokół Władysława grupują się elektorzy i książęta cesarstwa, jak arcyksiążę Maksymilian I Bawarski, Jan Jerzy II saski czy arcyksiążę Leopold, późniejszy cesarz; tu również znalazł się elektor brandenburski Fryderyk Wilhelm. Zwraca uwagę nieobecność na mapie cara Michała Romanowa.

„Księżyc a sprawa polska" w wersji Langrena to nie tylko uczczenie króla. $\mathrm{Na}$ mapie znajdują się bowiem również Jan Kazimierz ("Casimirus”, Po[loniae] P. [rinceps],, hetman wielki koronny Stanisław Koniecpolski (1594-1646) i kanclerz koronny Jerzy Ossoliński (1595-1650). Ich wybór zapewne ułatwiał fakt, że obaj 
mieli nadany przez cesarza tytuł książęcy (Ossoliński, podówczas już książę rzymski, w roku 1633, Koniecpolski cztery lata później). Dodajmy, że Ossoliński na Księżycu znalazł się - jak na kanclerza przystało - na Terra lustitiae. Zapewne nazwa krateru „Zamosci”, znajdującego się w tym samym południowym obszarze tarczy Księżyca co „Jan Kazimierz" i „Koniecpolski”, oznaczała Zamoyskiego. Byłby to może zmarły w 1638 r. Tomasz, kanclerz koronny. Co przecież najbardziej zwraca uwagę to szczególny wybór krateru „królewskiego". Jest to bowiem krater, od którego rozchodzą się promieniście jasne smugi na powierzchni Księżyca, wyróżniający się szczególnie jasnością w okresie pełni ${ }^{5}$.

$\mathrm{Na}$ uwagę zasługuje wreszcie i lokalizacja na mapie Langrena kraterów pomników uczonych. Skupieni są oni na północy, na Mare Astronomicum i Terra Honoris. Znajduje się tu znakomite grono uczonych od Talesa i Pitagorasa do Kopernika, Keplera i szeregu XVII-wiecznych astronomów. Dwa wyjątki od tej topografii to Galileusz i Heweliusz: szukać ich trzeba z dala od reszty, na południowym wschodzie tarczy Księżyca, w rejonie sąsiadującym z południową częścią Terra Dignitatis, rozjaśnianym przez wspomniane już jasne smugi wybiegające promieniście z krateru Władysława. Krater Heweliusza leży wprost na jednym z przedstawionych przez Langrena takich promieni. To usytuowanie zdaje się dobrze harmonizować z panegiryczną intencją autora, który mógł w taki sposób zasygnalizować zainteresowania dworu warszawskiego pracami zarówno Galileusza jak i Heweliusza.

Jednakże i bez tej supozycji mapa Langrena daje dość wyraźny obraz Rzeczypospolitej w połowie XVII wieku widzianej z perspektywy elity umysłowej Niderlandów: położona wprawdzie nie w centrum, ale znacząco obecna w nurcie życia politycznego i umysłowego Europy.

Współcześni selenografowie ${ }^{6}$ odrzucili langrenowski model 'upolitycznionego' nazewnictwa. Ostała się za to zasada wykorzystania w nazwach kraterów imion uczonych wszystkich epok. Tę przyjętą powszechnie normę wprowadzł już w roku 1651 konsekwentnie na mapę Księżyca boloński filoz of $i$ astronom, jezuita J. Riccioli, lokując w poszczególnych sektorach tarczy satelity uczonych różnych epok ${ }^{7}$.

\section{Przypisy}

' J. North, Thomas Harriot and the first telescopic obervations of sunspots [W:] Thomas Harriot. Renaissance scientist, Oxford 1974, s. 127-165.

${ }^{2}$ Wykorzystane tu informacje o księżycowych badaniach Langrena zaczerpnięto z pracy $O$. Van de Vyver, SJ, Lunar Maps of the XVIIth century, Vatican Observatory Publications vol. 1, Nr. 2, 1971, s. 71-83.

${ }^{3}$ Obie mapy reprodukowane są $w$ cyt. pracy Vyvera, fig. 7-9.

${ }^{4}$ Vyver, op. cit., s. 82.

${ }^{5}$ W ustalonej ostatecznie terminologii jest to krater "Tycho".

${ }^{6}$ J. Heweliusz, Selenographia, 1647; J.B. Riccioli, Almagestum novum, 1651.

${ }^{7}$ Jeden z sektorów grupowal uczonych nowożytnych, z Kopernikiem, Keplerem i Galileuszem. Riccioli tu whaśnie przyznal sobie skromnie niewielki krater na samym brzegu tarczy, w pobliżu Heweliusza. Langren natomiast znalazł się daleko, na przeciwległym skraju, w towarzystwie późnostarożytnych i średniowiecznych autorów lacińskich. 